Article

\title{
Tree Bark Phenols Regulate the Physiological and Biochemical Performance of Gladiolus Flowers
}

\author{
Hosam O. Elansary ${ }^{1,2}$ (D) \\ 1 Plant Production Department, College of Food and Agricultural Sciences, King Saud University, \\ P.O. Box 2455, Riyadh 11451, Saudi Arabia; helansary@ksu.edu.sa \\ 2 Floriculture, Ornamental Horticulture, and Garden Design Department, Faculty of Agriculture (El-Shatby), \\ Alexandria University, Alexandria 21545, Egypt
}

Received: 18 December 2019; Accepted: 3 January 2020; Published: 5 January 2020

\begin{abstract}
The postharvest physiology of cut flowers is largely dependent on vase life, which is the maximum number of days before flower senescence. The use of tree bark extracts (major forest plant residues), as an eco-friendly and natural antioxidant preservative in holding solutions, is a novel tool for extending flower longevity. The morphological, physiological, biochemical, and genetic responses of Gladiolus grandiflorus cut spikes to Magnolia acuminata and Taxus cuspidata bark extracts as additives in holding solutions were investigated. G. grandiflorus subjected to bark extracts as well as catechin and protocatechuic acid (main phenols) displayed significant increased longevity (up to 18 days), an increased number of open florets, and increased floret fresh weight. Increases in the relative water content, leaf chlorophyll, carotenoids, soluble sugars, and protein content were observed in addition to a reduction in microbial growth in the cut spikes. Gas exchange parameters were higher in the bark extract treatments than in the controls. Higher antioxidant activities were detected and associated with increased superoxide dismutase and catalase enzyme activities and reduced $\mathrm{H}_{2} \mathrm{O}_{2}$ accumulation. The bark extract treatments associated with reduced expression of $\mathrm{GgCyP} 1$ (produces cysteine protease) and increased expression of both GgDAD1 (defends against apoptotic activity) and GgEXPA1 (regulates petal expansion). Several mechanisms were implicated in these effects, including maintenance of water content, enhanced management of reactive oxygen species (ROS), increased sugar and protein composition, and control of microbial growth. Thus, bark extracts and isolated phenols could be developed as an eco-friendly, non-toxic, and cost-effective natural preservative for cut gladiolus flowers.
\end{abstract}

Keywords: antioxidants; phenols; Gladiolus; Magnolia; Taxus; vascular blockage; vase life

\section{Introduction}

Gladiolus grandiflorus, an important cut flower of the Iridaceae, exhibits a short vase life and loss of vitality. The vase life of cut spikes of gladioluses is subject to several physiological, biochemical, and genetic mechanisms that control flower senescence, such as water retention, gas exchange, membrane stability, oxidative stress, microbial effects, pigment (chlorophyll and carotenoids) maintenance, carbohydrate fluctuations, and genetic control [1-4]. Water pressure is controlled by the continuous supply of water from the vase holding solution to the petals through the xylem, which is subject to air embolism and bacterial accumulation in the vessels leading to vascular blockage [5]. This blockage causes a negative water balance because the water loss by respiration is higher than the gain through water absorption [6-8]. Reactive oxygen species, such as $\mathrm{H}_{2} \mathrm{O}_{2}$, affect cell membrane integrity by damaging proteins, lipids, pigments, and nucleic acids, which accelerates cut flower senescence. The antioxidative mechanism plays a major role in controlling flower senescence by activating enzymes, such as superoxide dismutase (SOD) and catalase (CAT), that antagonize the effects of reactive oxygen 
species [9-12]. Microbial growth affects the physiology of cut flowers by blocking vessels via the deposition of dead bacteria and the macromolecules formed through bacterial degradation. As with most cut flowers, gladioluses are harvested at the bud stage and most of the florets continue their growth in the vase using soluble sugar sources and water [8]. The greater the sugars for the cut spikes in the vase holding solution, the longer the vase life and greater the number of open florets. The use of sugars in the vase holding solution extends the vase life of most cut flowers; however, bacterial growth is much higher in holding solutions containing sugars. Many synthetic preservatives have been developed to control bacterial growth and prevent vascular blockage, but they might be toxic to the florets and reduce vase life [13]. Several studies have been conducted to determine strategies to extend the relatively short vase life of gladiolus flowers using synthetic or natural compounds (leaf extracts, $\mathrm{AgNO}_{3}$, nano-silver, and $\mathrm{Zn}$ ) [14-17]. However, the application of phenol-rich natural preservatives in cut spike holding solutions remains limited.

Tree bark, a natural product of forests, has several applications in agriculture and pharmaceutical industries. The bark of trees serves many physiological functions, including protection against harsh environments as well as insect and animal attacks, and is a storage site for carbohydrates and minerals [18,19]. Magnolia acuminata (Magnoliaceae), a common tree that grows naturally in Europe and North America, is used for traditional medicine due to its antibacterial activities [20,21]. Taxus cuspidata (Taxaceae), a tree that grows naturally in Asia, Europe, and North America, has some antibacterial, antifungal, and anticancer activities [21,22]. Both species have interesting phenolic profiles in their outer bark. The effects of tree bark extract as a natural, eco-friendly preservative for cut flower holding solutions have not been explored. The polyphenols, which are one of the most active plant secondary metabolites [23], are an important part of tree barks [21,24,25] and may have a critical role in prolonging cut flower vase life. A recent investigation on both species indicated that the bark extract is rich in phenolic compounds, including protocatechuic acid, hydroxycaffeic acid, and catechin [21].

This study aimed to explore the morphological, physiological, biochemical, and genetic responses of cut spikes of G. grandiflorus subjected to M. acuminata and T. cuspidata bark extracts as novel eco-friendly and cost-effective natural preservatives. The morphological, physiological, biochemical, and genetic parameters investigated included vase life, number of florets that opened, daily fresh weight of spikes, relative water content, gas exchange, chlorophyll and carotenoid content, lipid peroxidation, antioxidant enzyme activities, $\mathrm{H}_{2} \mathrm{O}_{2}$ production, and expression of senescence-related genes. Further, the effects of bark extracts and main isolated phenols (catechin and protocatechuic acid) on microbial growth at the stem ends was elucidated to explore the possible role of bark extracts in controlling vascular blockage and extending the vase life of cut flowers.

\section{Results}

\subsection{Morphological Responses and Bark Chemical Composition and Antioxidant Activities}

The vase life of cut spikes increased in plants subjected to moderate doses $\left(50 \mathrm{mg} \mathrm{L}^{-1}\right)$ of $M$ acuminata (MA) and T. cuspidata (TC) bark extracts as well as catechin and protocatechuic in the vase holing solution (Figure 1). The number of opened florets increased in cut spikes treated with 50-80 mg MA/TC. The longest vase life and the largest number of opened florets was observed in the treatment with $50 \mathrm{mg}$ MA. The daily spike fresh weight varied among treatments (Figure 1) during the $18 \mathrm{~d}$ of vase life. It increased during the first $6 \mathrm{~d}$ for spikes treated with bark extracts, and the highest fresh weight was found in the MA treatment at $50 \mathrm{mg}$, followed by the MA treatment at $80 \mathrm{mg}$. The fresh weight declined gradually in the control spikes starting with the 6th day, whereas other treatments retained their fresh weight. Chemical composition and antioxidant activities of the tree barks used is shown in Table 1. The total phenolics, soluble sugars, and antioxidant activities calculated by different methods are shown for each extract. The major identified phenols, as previously found, were protocatechuic acid, hydroxycaffeic acid, and catechin [21]. 

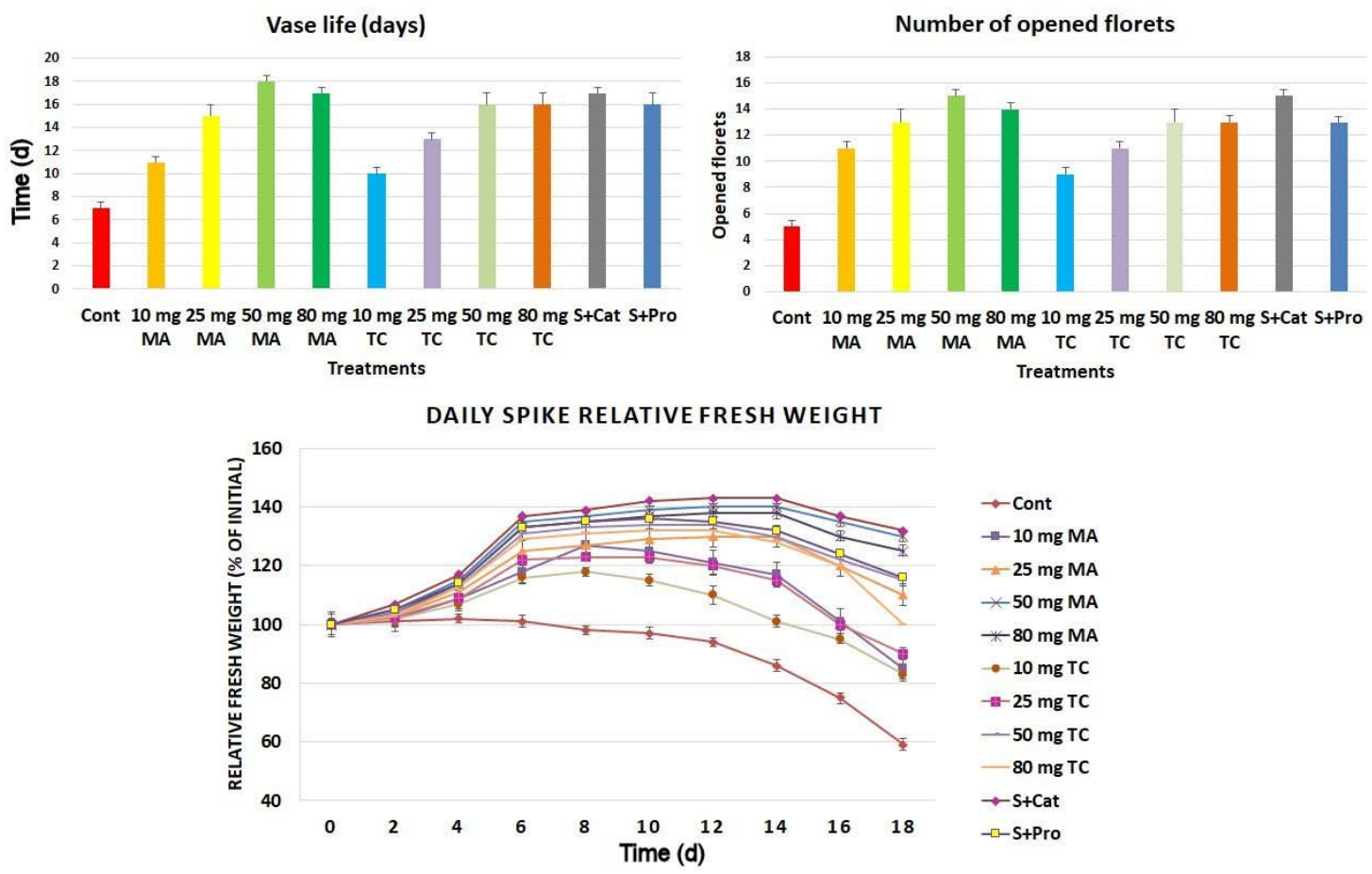

Figure 1. Longevity of spike florets (vase life), number of opened florets, and daily spike fresh weight of Gladiolus cut spikes subjected to serial concentrations of $M$. acuminata and T. cuspidata bark extracts $\left(10-80 \mathrm{mg} \mathrm{L}^{-1}\right)$ and catechin $\left(83.12 \mathrm{mg} \mathrm{g}^{-1}\right)$ plus sucrose $\left(35 \mathrm{mg} \mathrm{g}^{-1}\right)$, denoted as S+Cat, and protocatechuic acid $\left(21.08 \mathrm{mg} \mathrm{g}^{-1}\right)$ plus sucrose $\left(28 \mathrm{mg} \mathrm{g}^{-1}\right)$, denoted as $\mathrm{S}+$ pro. The values shown are the mean SE of $n=12$. Longevity was determined as the time required for $50 \%$ of the spike florets to lose turgor and wilt (loss of color, shedding of petals, slumping of spike head).

Table 1. Chemical composition and antioxidant activities of M. acuminata and T. cuspidata bark extracts. The values shown are the mean SE of $n=3$.

\begin{tabular}{|c|c|c|}
\hline Species & Chemical Compound & Amount \\
\hline \multirow{11}{*}{ M. acuminata } & Total phenolics & $32 \pm 0.53 \mathrm{mg} \mathrm{g}^{-1}$ \\
\hline & soluble sugars & $35 \pm 0.71 \mathrm{mg} \mathrm{g}^{-1}$ \\
\hline & Total antioxidants (DPPH) & $2.97 \pm 0.13\left(\mathrm{IC}_{50}, \mu \mathrm{g} \mathrm{mL}^{-1}\right)$ \\
\hline & Total antioxidants ( $\beta$-carotene-linoleic acid) & $3.5 \pm 0.12\left(\mathrm{IC}_{50}, \mu \mathrm{g} \mathrm{mL}^{-1}\right)$ \\
\hline & Total antioxidants (ABTS) & $1.6 \pm 0.1\left(\mathrm{IC}_{50}, \mu \mathrm{g} \mathrm{mL} \mathrm{m}^{-1}\right)$ \\
\hline & Identified phenolics & \\
\hline & Ellagic acid & $0.42 \pm 0.03\left(\mathrm{mg}_{\left.100 \mathrm{~g}^{-1}\right)}\right.$ \\
\hline & Protocatechuic acid & $15.01 \pm 0.9\left({\left.\mathrm{mg} 100 \mathrm{~g}^{-1}\right)}^{\prime}\right.$ \\
\hline & Catechin & $83.12 \pm 1.35\left(\mathrm{mg}_{\left.100 \mathrm{~g}^{-1}\right)}\right.$ \\
\hline & Epicatechin & $21.54 \pm 1.01\left(\mathrm{mg} 100 \mathrm{~g} \mathrm{~g}^{-1}\right)$ \\
\hline & Epigallocatechin gallate & $13.13 \pm 0.17\left(\mathrm{mg} 100 \mathrm{~g}^{-1}\right)$ \\
\hline \multirow{12}{*}{ T. cuspidata } & Total phenolics & $26 \mathrm{mg} \mathrm{g}^{-1}$ \\
\hline & soluble sugars & $28 \mathrm{mg} \mathrm{g}^{-1}$ \\
\hline & DPPH radical scavenging activity & $4.0 \pm 0.2\left(\mathrm{IC}_{50}, \mu \mathrm{g} \mathrm{mL}-1\right)$ \\
\hline & $\beta$-carotene bleaching inhibition activity & $4.7 \pm 0.2\left(\mathrm{IC}_{50}, \mu \mathrm{g} \mathrm{mL} \mathrm{m}^{-1}\right)$ \\
\hline & ABTS radical scavenging activity & $2.0 \pm 0.1\left(\mathrm{IC}_{50}, \mu \mathrm{g} \mathrm{mL} \mathrm{mL}^{-1}\right)$ \\
\hline & Identified phenolics & \\
\hline & Caffeic acid & $3.12 \pm 0.03\left(\mathrm{mg}_{\left.100 \mathrm{~g}^{-1}\right)}\right.$ \\
\hline & Chlorogenic acid & $8.20 \pm 0.56\left(\mathrm{mg}^{\left.100 \mathrm{~g}^{-1}\right)}\right.$ \\
\hline & Gallic acid & $2.1 \pm 0.09\left(\mathrm{mg}_{\left.100 \mathrm{~g}^{-1}\right)}\right.$ \\
\hline & p-Hydroxybenzoic acid & $2.13 \pm 0.09\left(\mathrm{mg}_{100 \mathrm{~g}^{-1}}\right)$ \\
\hline & Hydroxycaffeic acid & $22.76 \pm 0.8\left(\mathrm{mg} 100 \mathrm{~g}^{-1}\right)$ \\
\hline & Protocatechuic acid & $21.08 \pm 1.23\left(\mathrm{mg}_{\left.100 \mathrm{~g}^{-1}\right)}\right.$ \\
\hline
\end{tabular}




\subsection{Physiological Responses}

The relative water content of the untreated control was largely reduced compared to that of the bark extract-treated holding solutions (Figure 2). The application of 50 and $80 \mathrm{mg} \mathrm{MA}, 50 \mathrm{mg} \mathrm{TC}$, and catechin plus sucrose ( $\mathrm{S}+\mathrm{Cat}$ ) led to the highest relative water content during the 18 days postharvest. The chlorophyll content of the leaves had higher reduction rates in the control spikes compared to that of the bark extract-treated cut spikes (Figure 3). The highest chlorophyll content was found in the leaves of the cut spikes treated with 50 and $80 \mathrm{mg}$ MA as well as S+Cat. During the 18 days postharvest, the carotenoid composition exhibited lower reduction in the cut spikes treated with bark extracts than in the controls; a higher amount of carotenoids was found in spikes treated with different concentrations of bark extracts.

\section{RELATIVE WATER CONTENT \%}

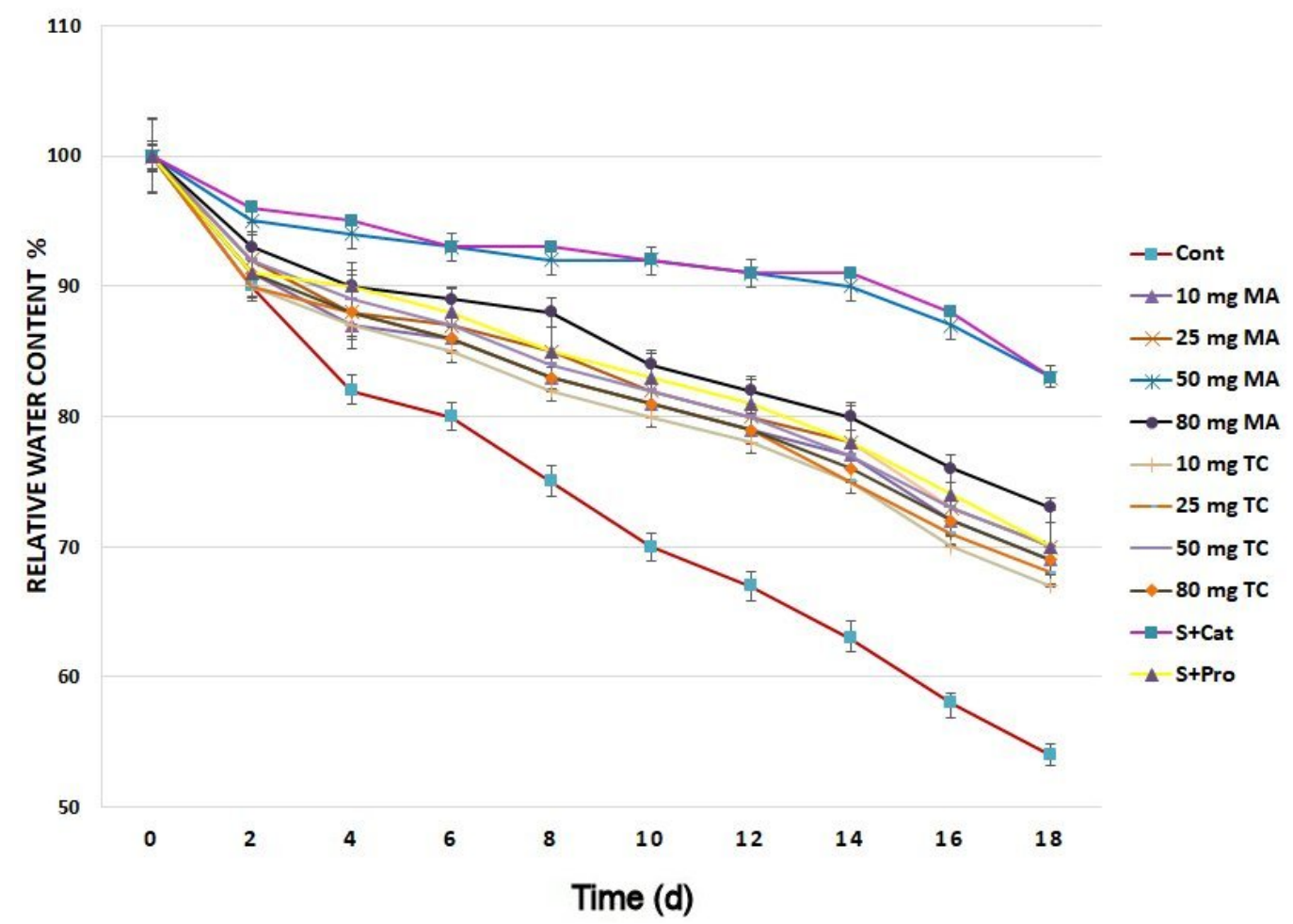

Figure 2. Relative water content of Gladiolus cut spikes subjected to serial concentrations of M. acuminata and T. cuspidata bark extracts and catechin $\left(83.12 \mathrm{mg} \mathrm{g}^{-1}\right)$ plus sucrose $\left(35 \mathrm{mg} \mathrm{g}^{-1}\right)$, denoted as S+Cat and protocatechuic acid $\left(21.08 \mathrm{mg} \mathrm{g}^{-1}\right)$ plus sucrose $\left(28 \mathrm{mg} \mathrm{g}^{-1}\right)$, denoted as $\mathrm{S}+$ pro. The values shown are the mean SE of $n=12$. 


\section{CHLOROPHYLL CONTENT}

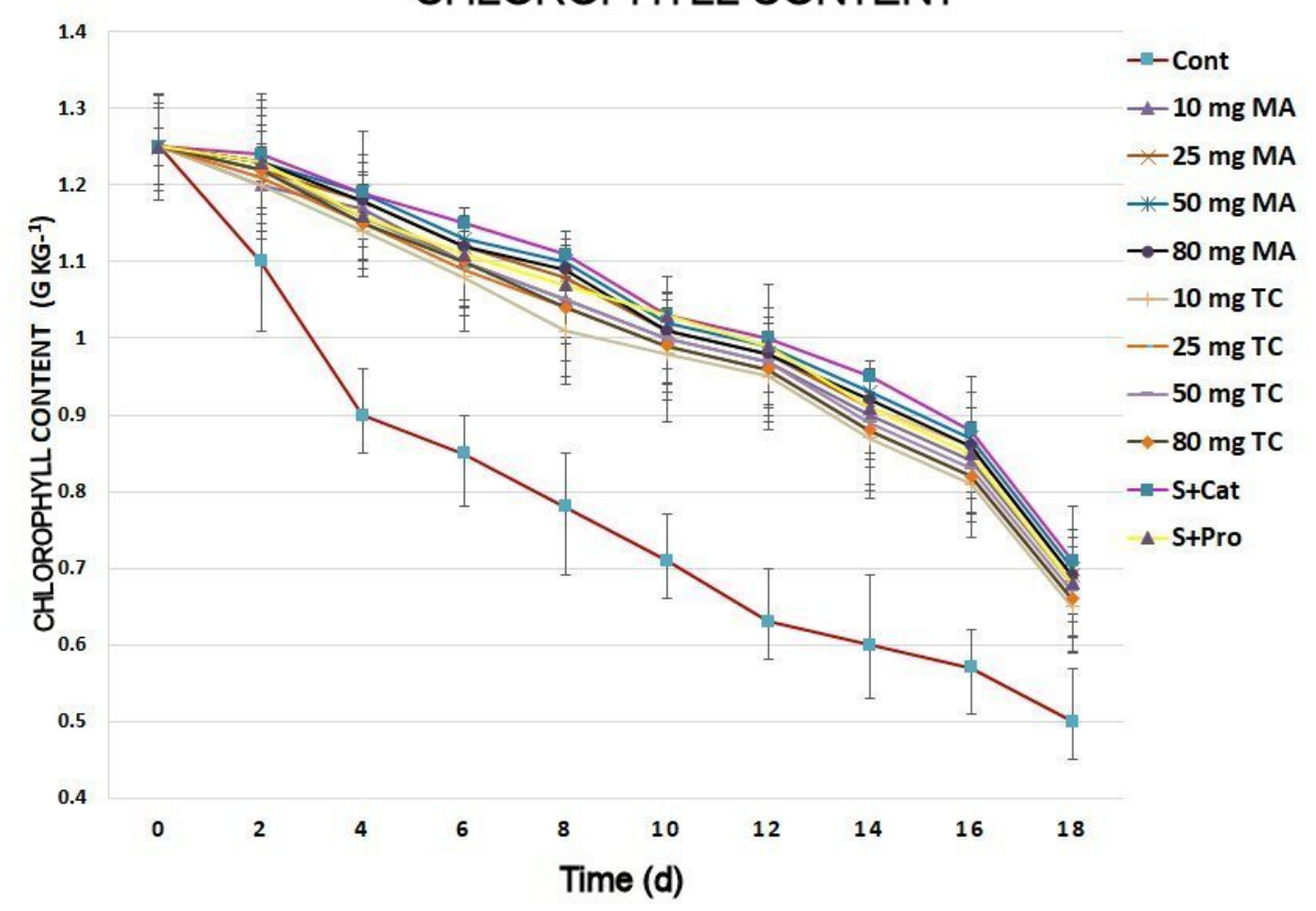

CAROTENOID

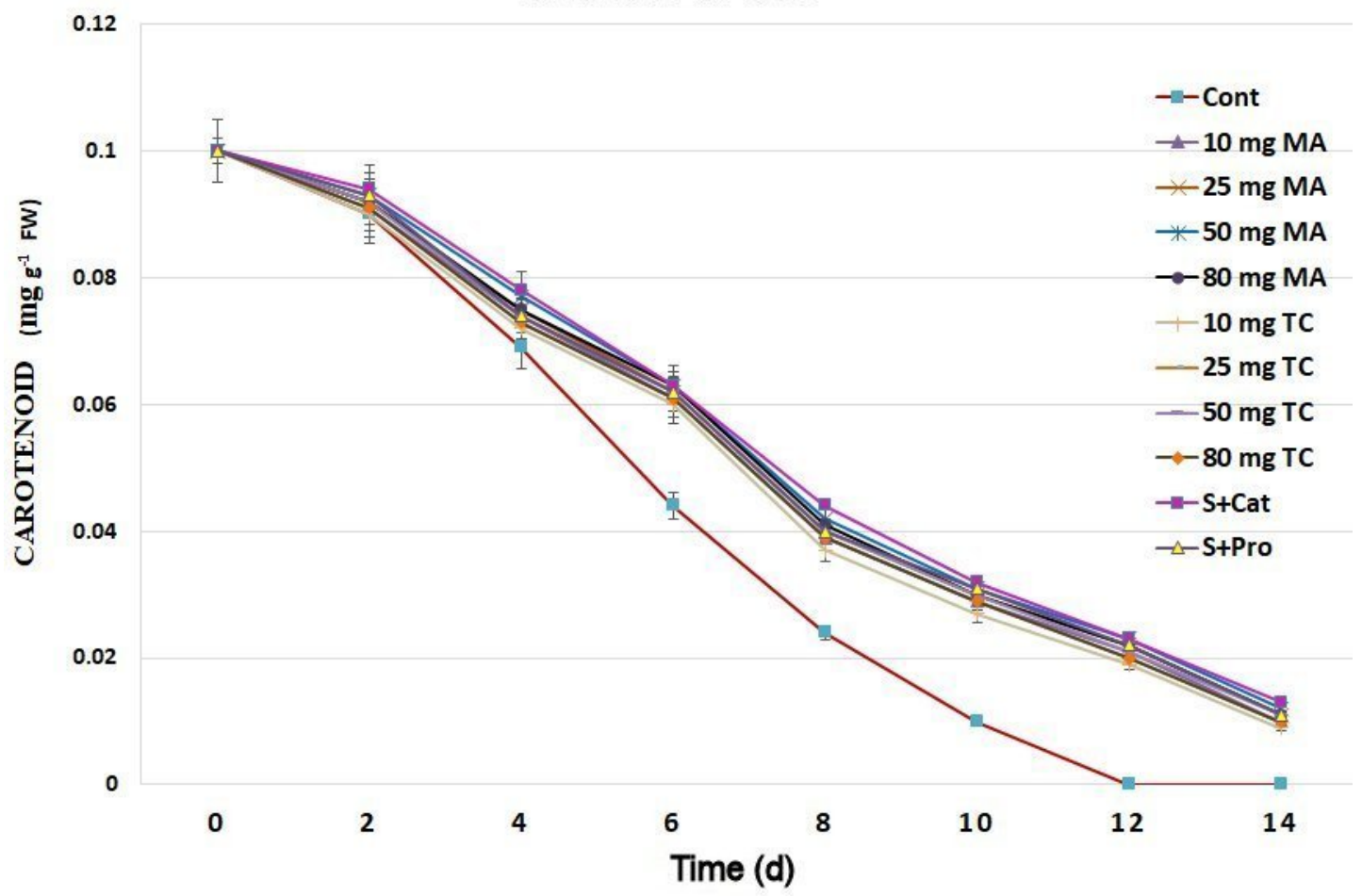

Figure 3. Chlorophyll and carotenoid content of Gladiolus cut spikes subjected to serial concentrations of M. acuminata and T. cuspidata bark extracts and catechin $\left(83.12 \mathrm{mg} \mathrm{g}^{-1}\right)$ plus sucrose $\left(35 \mathrm{mg} \mathrm{g}^{-1}\right)$, denoted as S+Cat and protocatechuic acid $\left(21.08 \mathrm{mg} \mathrm{g}^{-1}\right)$ plus sucrose $\left(28 \mathrm{mg} \mathrm{g}^{-1}\right)$, denoted as S+pro. The values shown are the mean SE of $n=12$. The carotenoid composition was very low and not comparable after day 14 . 
Soluble sugars initially increased and then remained stable in the bark-extract, catechin, and protocatechuic treatments during the first 6 days postharvest compared to those in the control, in which they were reduced on the 2nd day (Figure 4). After day 6, the amount of soluble sugars began to decline and was similar to that of the control by day 18 . Soluble proteins increased in all treatments during the first 2 days and, then, began to decline in the control. Cut spikes treated with bark extracts showed additional increases in soluble protein until day 4, which then decreased slowly until day 18. Treatments with 50 and $80 \mathrm{mg}$ MA as well as S+Cat led to higher amounts of soluble sugars and proteins compared to those of the other treatments.
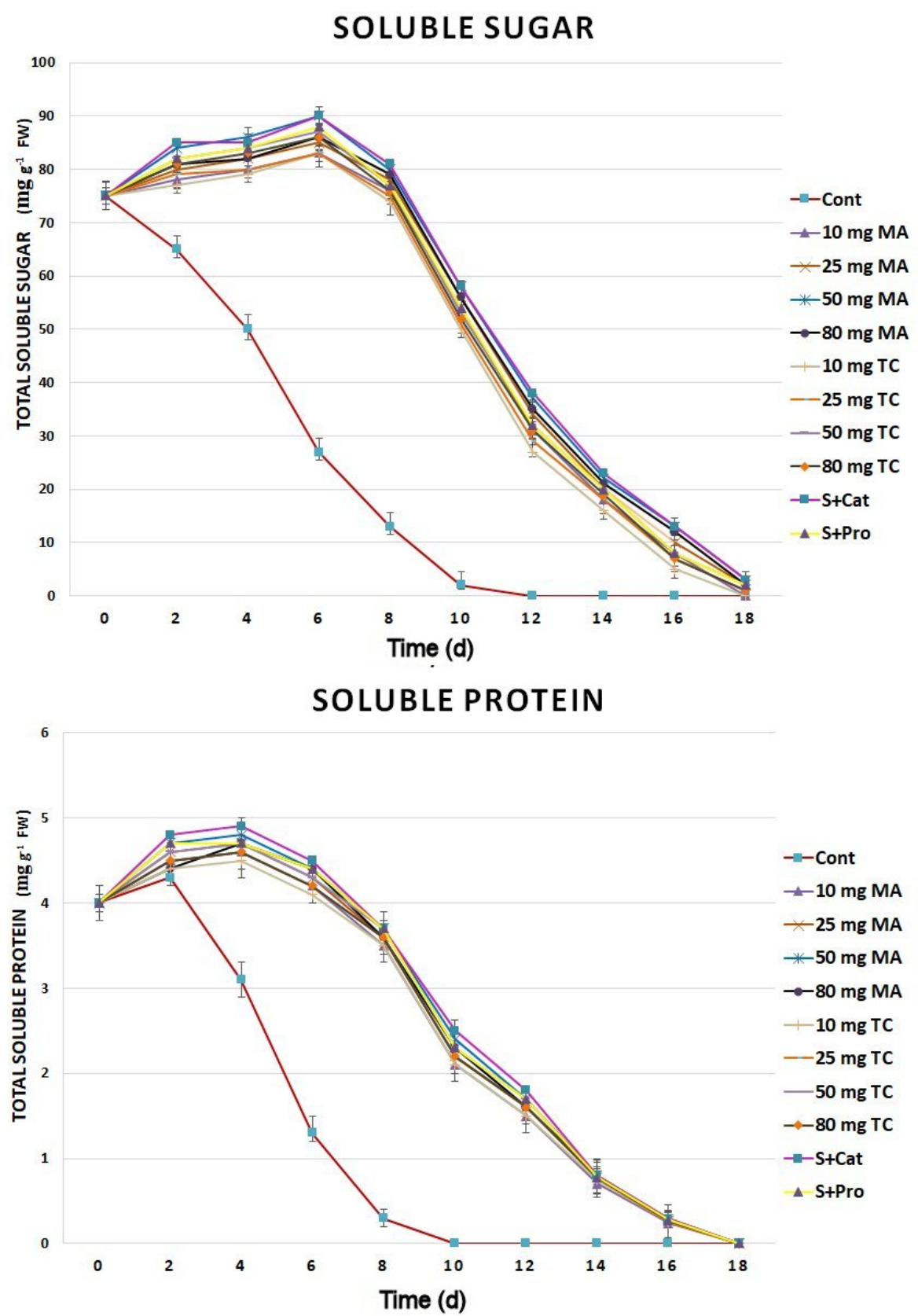

Figure 4. Soluble sugar and soluble protein content of Gladiolus cut spikes subjected to serial concentrations of M. acuminata and T. cuspidata bark extracts and catechin $\left(83.12 \mathrm{mg} \mathrm{g}^{-1}\right)$ plus sucrose $\left(35 \mathrm{mg} \mathrm{g}^{-1}\right)$, denoted as $\mathrm{S}+\mathrm{Cat}$, and protocatechuic acid $\left(21.08 \mathrm{mg} \mathrm{g}^{-1}\right)$ plus sucrose $\left(28 \mathrm{mg} \mathrm{g}^{-1}\right)$, denoted as $\mathrm{S}+$ pro. The values shown are the mean SE of $n=12$. 
Gas exchange showed a noticeable improvement in cut spikes treated with bark extracts and phenols compared to that in the control (Figure 5). Lower decreases in stomatal conductance, transpiration, and photosynthetic rates were observed in the bark extract-treated groups compared to those of the control during the postharvest period. The slowest decreases were found in the cut spikes treated with 50 and $80 \mathrm{mg}$ of MA as well as S+Cat compared to those of other bark-extract treatments. The bacterial count was largely reduced in the bark extract-treated spikes compared to that of the controls (Figure 6). The highest reductions in bacterial counts occurred in treatments with 50 and $80 \mathrm{mg}$ MA and $50 \mathrm{mg}$ TC. Different bacteria were identified and included: Enterobacter spp., Pseudomonas spp., and Bacillus spp.
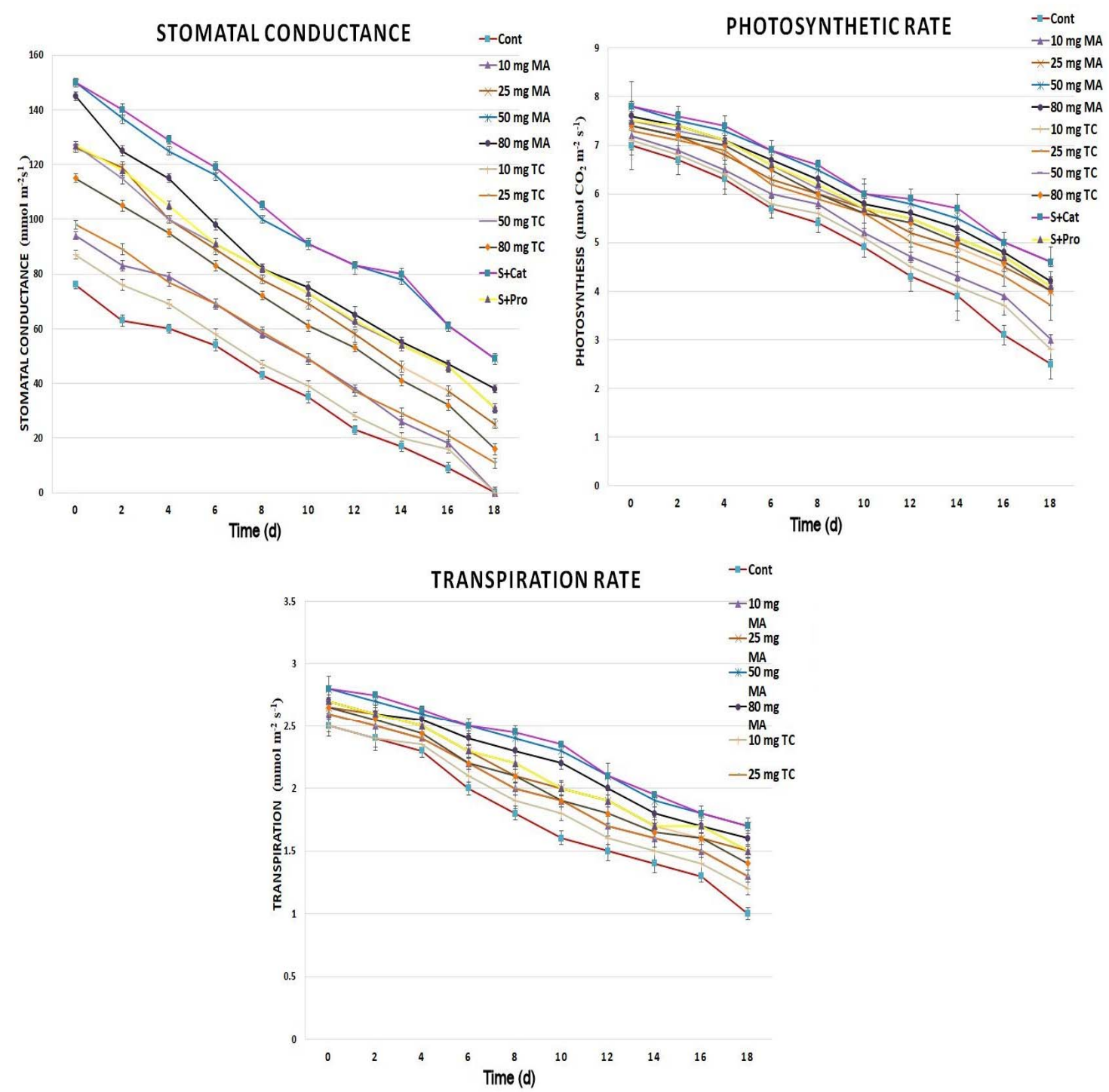

Figure 5. Gas exchange parameters of Gladiolus cut spikes subjected to serial concentrations of $M$. acuminata and T. cuspidata bark extracts $\left(\mathrm{mg} \mathrm{g}^{-1}\right)$ and catechin $\left(83.12 \mathrm{mg} \mathrm{g}^{-1}\right)$ plus sucrose $\left(35 \mathrm{mg} \mathrm{g}^{-1}\right)$, denoted as S+Cat, and protocatechuic acid $\left(21.08 \mathrm{mg} \mathrm{g}^{-1}\right)$ plus sucrose $\left(28 \mathrm{mg} \mathrm{g}^{-1}\right)$, denoted as $\mathrm{S}+$ pro. The values shown are the mean SE of $n=12$. 


\section{BACTERIAL COUNT}

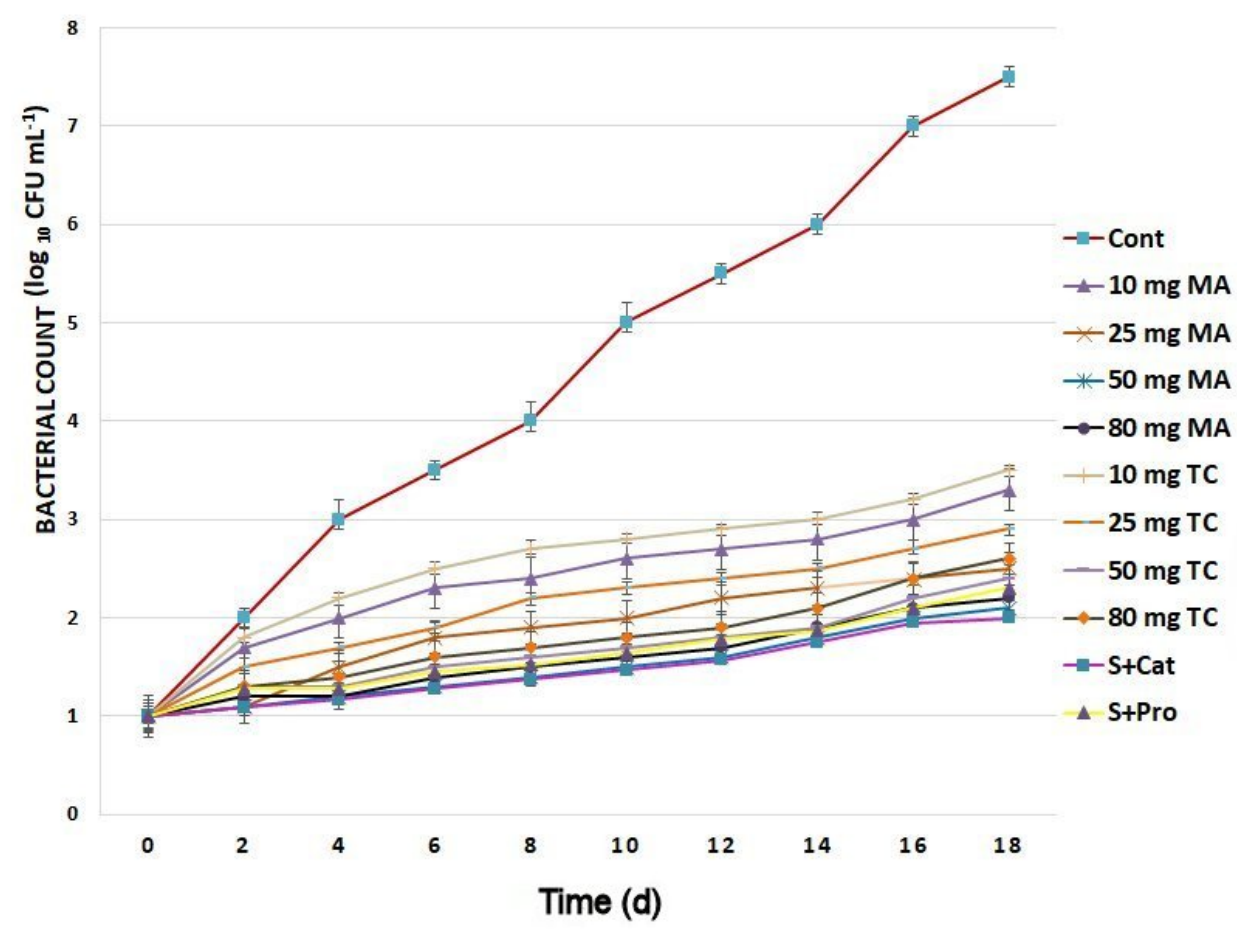

Figure 6. Bacterial counts of Gladiolus cut spikes subjected to serial concentrations of M. acuminata and T. cuspidata bark extracts and catechin $\left(83.12 \mathrm{mg} \mathrm{g}^{-1}\right)$ plus sucrose $\left(35 \mathrm{mg} \mathrm{g}^{-1}\right)$, denoted as $\mathrm{S}+\mathrm{Cat}$, and protocatechuic acid $\left(21.08 \mathrm{mg} \mathrm{g}^{-1}\right)$ plus sucrose $\left(28 \mathrm{mg} \mathrm{g}^{-1}\right)$, denoted as $\mathrm{S}+$ pro. The values shown are the mean SE of $n=12$.

\subsection{Biochemical Responses and Expression Analyses}

The lipid peroxidation assay revealed higher antioxidant activities in the cut spikes treated with bark extracts than in the control; the highest antioxidant activities were found in spikes treated with $50 \mathrm{mg}$ MA as well as S+Cat (Figure 7). CAT enzyme activity was much higher in spikes treated with bark extracts than in the control for the 18 days postharvest. The highest enzyme activities were found in the $50 \mathrm{mg}$ MA treatments. SOD activity increased in cut spikes subjected to bark extracts for 6 days and, then, reduced gradually to match that of the control by day 18 (Figure 8). The $\mathrm{H}_{2} \mathrm{O}_{2}$ content increased rapidly in the control cut spikes following harvest, whereas it decreased gradually in the bark-extract and isolated phenols-treated samples during the 18 days postharvest. 


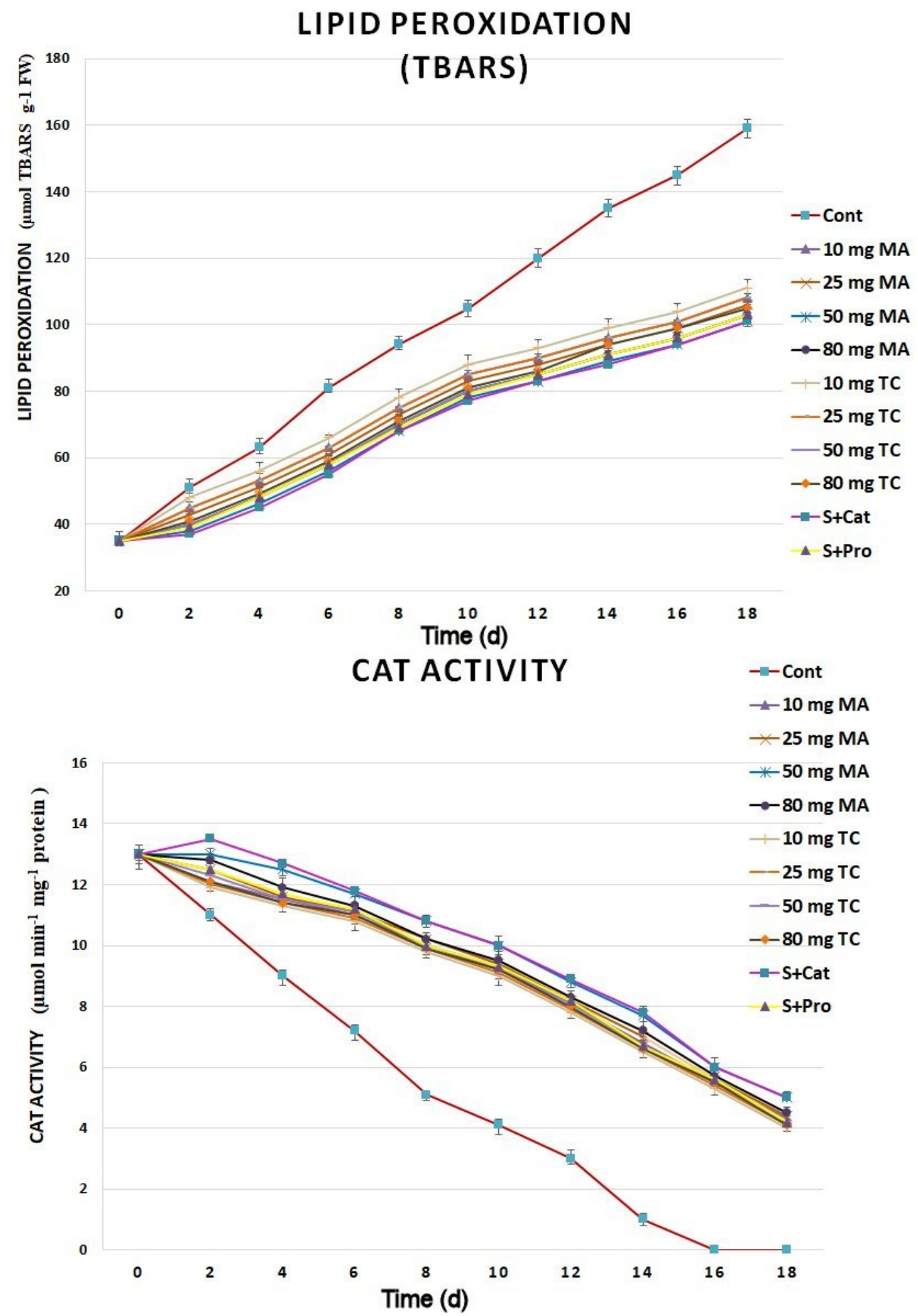

Figure 7. TBARS and CAT activity in the petal tissues of Gladiolus cut spikes subjected to serial concentrations of M. acuminata L. and T. cuspidata bark extracts and catechin $\left(83.12 \mathrm{mg} \mathrm{g}^{-1}\right)$ plus sucrose (35 $\left.\mathrm{mg} \mathrm{g}^{-1}\right)$, denoted as $\mathrm{S}+\mathrm{Cat}$, and protocatechuic acid $\left(21.08 \mathrm{mg} \mathrm{g}^{-1}\right)$ plus sucrose $\left(28 \mathrm{mg} \mathrm{g}^{-1}\right)$, denoted as S+pro. The values shown are the mean SE of $n=12$. 

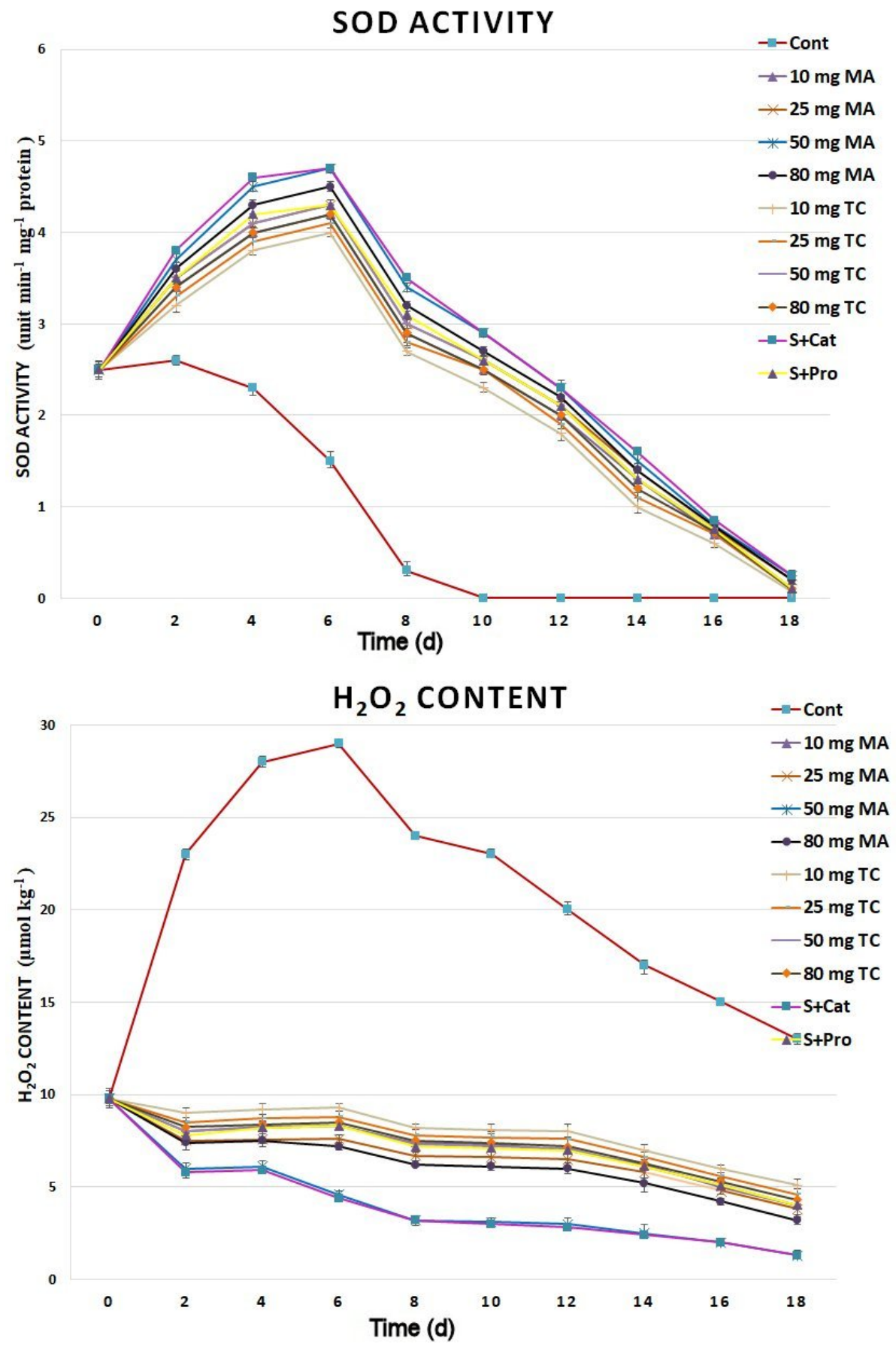

Figure 8. $\mathrm{H}_{2} \mathrm{O}_{2}$ and SOD activities in the petal tissues of Gladiolus cut spikes subjected to serial concentrations of M. acuminata L. and T. cuspidata bark extracts and catechin $\left(83.12 \mathrm{mg} \mathrm{g}^{-1}\right)$ plus sucrose (35 $\left.\mathrm{mg} \mathrm{g}^{-1}\right)$, denoted as $\mathrm{S}+\mathrm{Cat}$, and protocatechuic acid $\left(21.08 \mathrm{mg} \mathrm{g}^{-1}\right)$ plus sucrose $\left(28 \mathrm{mg} \mathrm{g}^{-1}\right)$, denoted as S+pro. The values shown are the mean SE of $n=12$.

In the normal case (control), the expression of $G g C y P 1$ increased during senescence (Figure 9). All bark extract treatments and isolated phenols showed decreased $G g C y P 1$ expression; however, MA bark extract and $\mathrm{S}+\mathrm{Cat}$ treatments showed the lowest expression of this gene. Bark extract treatments upregulated the expression of GgDAD1 (senescence responsible) and GgEXPA1 (GA-alpha-expansin) compared to that of the control. 


\section{GgCyP1}

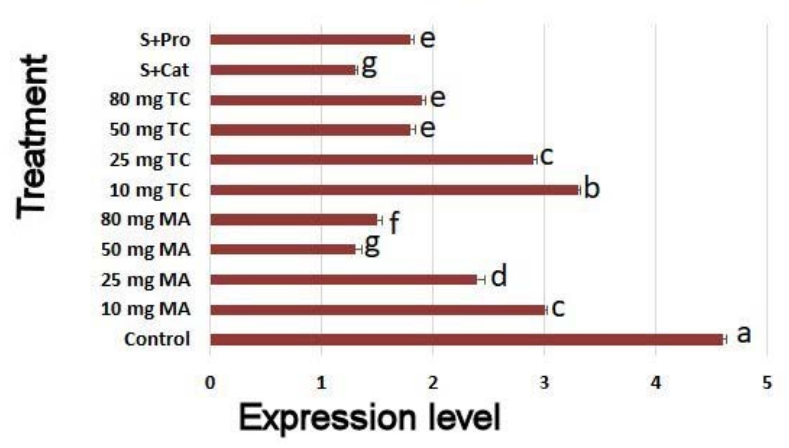

GgDAD1

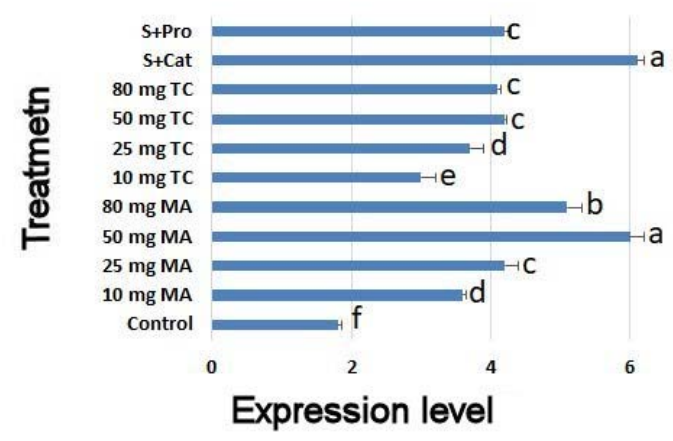

GqEXP1

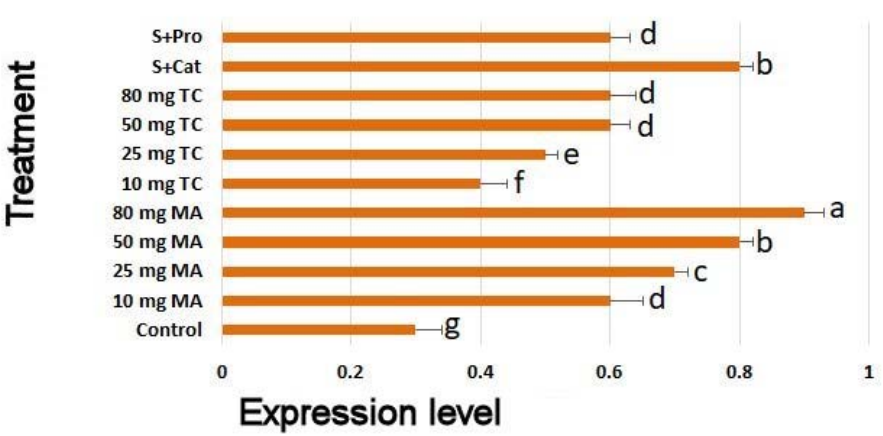

Figure 9. $G g C y P 1, G g D A D 1$, and $G g E X P A 1$ expression in the petal tissues of Gladiolus cut spikes subjected to serial concentrations of M. acuminata L. and T. cuspidata bark extracts and catechin $\left(83.12 \mathrm{mg} \mathrm{g}^{-1}\right)$ plus sucrose $\left(35 \mathrm{mg} \mathrm{g}^{-1}\right)$, denoted as $\mathrm{S}+\mathrm{Cat}$, and protocatechuic acid $\left(21.08 \mathrm{mg} \mathrm{g}^{-1}\right)$ plus sucrose $\left(28 \mathrm{mg} \mathrm{g}^{-1}\right)$, denoted as $\mathrm{S}+$ pro. The values shown are the mean SE of $n=12$.

\section{Discussion}

Extended longevity, more opened florets, and enhanced spike weight are indicators of increased postharvest quality of gladiolus cut spikes, which could be attributed to the novel positive effects of bark extracts and respective phenols on relative water content and the inhibition of microbial growth. Other important factors affecting these positive attributes include enhanced gas exchange and increased chlorophyll and carotenoid content. The antioxidant activities of bark extracts were evident in reduced $\mathrm{H}_{2} \mathrm{O}_{2}$ accumulation and increased antioxidants as well as CAT and SOD activities. The addition of chemicals, such as silver nanoparticles, to cut flower holding solutions increases vase life because of antioxidant mechanisms that delay senescence [26]. Carotenoids and polyphenols are the major antioxidants in ornamental flowers [27]. Senescence was delayed due to the high polyphenol composition of bark extracts. In the current study, we delayed senescence by several mechanisms, including gas exchange control. Improved gas exchange results from increased stomatal conductance, transpiration, and photosynthetic rates. The relatively high sugar composition of tree bark, as found in this study, was related to increased photosynthetic and transpiration rates [28] and stomatal conductance [29]. Increased fresh weight and number of opened florets indicated higher sugar composition of the holding solution and improved growth and longevity of the treated cut spikes.

The improved growth of cut spikes subjected to bark-extract treated holding solutions was strongly related to improved water supply and reduced microbial growth, as documented by the monitoring of stem end bacterial growth in this study. Bacterial occlusion is one of the key factors in water transport in cut flower stems [30]. In the current study, the bacterial blockage was not investigated. However, the bacterial growth in the vase holding solutions treated with bark extract was largely reduced 
owing to the presence of several phenols and catechins, such as protocatechuic acid and catechin. Hydroxycaffeic acid had no effect on the bacterial growth or other morphological and physiological parameters (data not shown). Protocatechuic acid and catechin show strong antimicrobial activities against different bacteria [31,32]. In addition, the high phenolic composition of the bark extracts exerted strong inhibitory effects against the growth of microorganisms [33]. The phenolic profile of bark extracts used in this study was strongly related to the extended vase life of gladiolus flowers. A single report suggested that some phenols may play regulatory roles in iris flowers [34]; however, this is the first report, to our knowledge, indicating that bark extract phenols have physiological and biochemical activities on gladiolus cut spikes.

The relative water content of cut spikes subjected to bark extract-treated holding solutions was much higher than that of the control. This indicated reduced bacterial growth in the vase holding solutions and, consequently, in the xylem vessels as well as lower accumulation of bacterial residues in the holding solution. Enterobacter spp., Pseudomonas spp., and Bacillus spp. were identified in the stem of gladiolus cut flowers in this study and matched previous investigations on cut flowers of other species $[35,36]$. These genera are sensitive to phenolic compounds as found in several studies [24,37-40].

The higher relative water content of cut spikes is a major indicator of the improved growth and increased vase life in response to bark-extract treatment. The increased chlorophyll and sugar content of cut spikes following bark-extract treatments indicated improved longevity in response to the overall enhanced physiological status. The reduction in chlorophyll and carotenoids in control plants indicated a water deficiency and increased oxidation because reduced chlorophyll composition is a major sign of deficient water uptake in cut flowers [41]. Carbohydrates are important for the longevity of cut flowers because sugars are needed for the opening of buds, growth after harvest, and maintenance of physiological functionality. The addition of sugars, such as sucrose, to the vase holding solution is a common practice in the cut flower industry and the bark extracts used in this study contained natural sugars. However, the sugars within the holding solutions increased microbial growth, such that the addition of natural preservatives, including phenolic compounds, has proven to be effective in the control of bacterial growth, as in this study.

The increased protein in cut spikes treated with bark extracts was a strong indicator of continued growth and longer vase life because oxidative stress adversely affects intercellular protein formation and accumulation. The noticeable improvement in gas exchange in cut spikes treated with bark extracts as well as catechin and protocatechuic was a key indicator of the improved physiological status of treated cut spikes. Several chemicals used in the floriculture industry are known to increase the gas exchange of treated cut flowers, such as nano-silver [30].

The oxidative stress resulting from free radicals, such as $\mathrm{H}_{2} \mathrm{O}_{2}$, in cut flowers causes severe damage to intercellular proteins, pigments, lipids, and nucleic acids. Antioxidant enzymes, such as SOD and CAT, scavenge these free radicals and antagonize the oxidative stress effects [42]. Reductions in the oxidative stress of bark extract-treated cut spikes were observed, which were attributed to many factors, including the presence of phenols in the bark extracts, the stimulatory activities of bark extracts on antioxidant enzymes, and the physiological improvement of treated spikes. Previous investigations on other chemicals used to extend the vase life of cut flowers showed increased activities of antioxidant enzymes, such as SOD and CAT [26,43]. In this study, reductions in the $\mathrm{H}_{2} \mathrm{O}_{2}$ content of bark extract-treated spikes were observed, which confirmed the positive effects of these natural materials in controlling the oxidative stress mechanism in gladiolus cut spikes. The reduction in $\mathrm{H}_{2} \mathrm{O}_{2}$ was attributed to increased activities of SOD and CAT enzymes and the reduction of lipid peroxidation in treated cut spikes.

The expression of $G g C y P 1$ produces cysteine protease, which is known to increase during senescence [44]. In the current study, we found that bark extracts downregulated $G g C y P 1$ expression, which indicated that bark extracts and its phenolics increased cut spike longevity by reducing the speed of senescence. This finding is novel and has not been reported previously with regard to bark extracts. 
Furthermore, the expression of $G g D A D 1$ and $G g E X P A 1$ increases during floral expansion during the postharvest phase of gladiolus flowers $[45,46]$. Both genes showed significant increases in their expressions in bark extracts and its phenolics, which indicated that the death process was reduced, and there was a delay in flower senescence in treated cut spikes. Moreover, the protease activity was reduced.

\section{Material and Methods}

\subsection{Preparation and Analyses of Bark Extracts}

Outer bark samples of Magnolia acuminata L. and Taxus cuspidata Siebold \& Zucc were obtained from the Arboretum of the University of Guelph, Canada. The specimens were identified by Hosam Elansary and vouchered (Hosam000981 and Hosam000982-2019). Bark samples were oven dried $\left(35^{\circ} \mathrm{C}\right)$ until a constant weight, ground into a fine powder, and stored $\left(-20^{\circ} \mathrm{C}\right)$. Ground bark samples $(5 \mathrm{~g})$ were extracted overnight in a Soxhlet apparatus using methanol (99\%). The crude extracts were concentrated and dried in a vacuum rotary evaporator $\left(35^{\circ} \mathrm{C}\right)$. The working stock solution was prepared from bark samples dissolved in $500 \mu \mathrm{L}$ dimethyl sulfoxide (DMSO) and, then, diluted with distilled water to final serial concentrations of $10,25,50$, and $80 \mathrm{~g} 0.5 \mathrm{~L}^{-1}$. The working stock solutions were passed through a $0.45-\mu \mathrm{m}$ polytetrafluorethylene nylon filter and, then, stored at $-20^{\circ} \mathrm{C}$. These solutions were used as the vase solution for cut flowers. Comprehensive phenol and catechin analyses were performed on the extracts using HPLC-DAD, according to a previously described method [21]. The major compounds, as described before, were protocatechuic acid, hydroxycaffeic acid, and catechins, as shown in Table 1. The HPLC-DAD focused on this group of phenols because the research group [21] is specialized on the quantification of this group of phenols. Total phenolics content [47], soluble sugars [48], and antioxidants were determined using 2,2'-diphenypicrylhydrazyl (DPPH), $\beta$-carotene-linoleic acid [47], and 2,2'-azinobis-3-ethylbenzothiazoline-6-sulfonic acid (ABTS) [49]. The wavelength of $470 \mathrm{~nm}$ was used in the $\beta$-carotene bleaching experiment, while the wavelength of $517 \mathrm{~nm}$ was used in the DPPH to determine the absorbance. Bark extracts amount required to scavenge $50 \%$ of the $\beta$-carotene bleaching/DPPH solutions was considered as the $\mathrm{IC}_{50}\left(\mu \mathrm{g} \mathrm{mL} \mathrm{L}^{-1}\right)$ and was calculated by plotting the inhibition percent against extract concentration. The Fluorescence recovery after photobleaching (FRAP) experiment reagent was prepared following previous studies (e.g., [43]) using tripyridyl triazine (TPTZ, Sigma-Aldrich, Berlin, Germany). Aliquots $(100 \mu \mathrm{L})$ of bark extracts/Trolox (Sigma-Aldrich, Berlin, Germany) were added to the reagent $(3 \mathrm{~mL})$ and mixed. The mixture was incubated for $30 \mathrm{~min}$ at $37^{\circ} \mathrm{C}$ and the absorbance was determined at $593 \mathrm{~nm}$. The calibration procedure was accomplished using serial dilutions of Trolox $(0-0.5 \mathrm{M} \mathrm{mol} / \mathrm{L})$. Three sets of triplicate replications were conducted for all experiments. The chemical components on a dry weight (DW) basis of both extracts are given in Table 1.

\subsection{Plant Material and Treatments}

Homogenous Gladiolus grandiflorus Andrews Friendship cut spikes, with 15-17 buds and the first floret showing color, were obtained from commercial growers in Alexandria, Egypt, during March 2018. The plants $(68-75 \mathrm{~cm})$ were identified by Hosam Elansary and vouchered at the Faculty of Agriculture, Alexandria University. The spikes were cut in air to $68 \mathrm{~cm}$ and the lower leaves were removed. The working solutions of M. acuminata and T. cuspidata bark extracts were used as cut spike holding solutions in $0.5 \mathrm{~L}$ beakers. Non-treated spikes were kept in distilled water with comparable amount of DMSO as in extracts and considered the control. All stems per treatment were in the one beaker. Vase solutions were changed on a daily basis, except in the bacterial count experiment (solutions were not changed). A complete randomized block design was used with 3 replicates of 12 flowers each. Sucrose, as the major sugar in trees [50], plus specific isolated phenols (e.g., catechin, hydroxycaffeic acid, and protocatechuic acid) were used in vase solutions for comparison reasons. 


\subsection{Morphological Parameters}

The longevity of gladiolus flowers was determined under laboratory temperature $\left(25 \pm 2{ }^{\circ} \mathrm{C}\right)$, relative humidity $(80 \pm 3 \%)$, photoperiod $(14 \mathrm{~h})$, and irradiance $\left(10 \mu \mathrm{mol} \mathrm{m}^{-2} \mathrm{~s}^{-1}\right)$. Longevity was determined as the time required for $5 \%$ of the spike florets to lose turgor and wilt (loss of color shedding of petals, slumping of spike head). The number of opened florets was determined for each spike during the experiment. Daily spike fresh weight (FW) was determined during the experiment on the 2nd, 4th, 6th, 8th, 10th, 12th, 14th, 16th, and 18th $\mathrm{d}$, as previously described [51].

\subsection{Physiological and Biochemical Measurements}

Relative water content (RWC) was determined using fresh petals on the 2nd, 4th, 6th, 8th, 10th, $12^{\text {th }}, 14$ th, 16 th, and 18 th $\mathrm{d}$. The turgid weight was determined by dipping petals in water for $4 \mathrm{~h}$ and the dry weight was determined by placing them in a drying oven $\left(35^{\circ} \mathrm{C}\right)$ until a constant weight was achieved [52]. Gas exchange parameters (stomatal conductance, net photosynthetic rate, and transpiration rate) were determined in the remaining leaves on the $2 \mathrm{nd}, 4$ th, 6 th, 8 th, 10 th $, 12^{\text {th }}, 14$ th, 16 th, and 18th $\mathrm{d}$ after harvest using a photosynthesis analyzer (Bioscientific Ltd., Hoddesdon, UK), according to a previously described method [9].

The total chlorophyll and carotenoid content was quantified according to a previously described method [53]. The total soluble sugars in the petals were determined as per the method described by Maity [26] and the total soluble proteins were determined using a previously reported method [54]. Lipid peroxidation levels were expressed as thiobarbituric acid reactive substances (TBARS), $\mathrm{H}_{2} \mathrm{O}_{2}$, CAT, and SOD activities and quantified in frozen petal tissues [54].

Stem end microbial growth was determined by excising the ends, washing them with distilled water, and grinding. The ground material was diluted with $0.9 \%$ normal saline and $0.1 \mathrm{~mL}$ aliquots of each sample were taken on the 2nd, 4th, 6th, 8th, 10th, 12th 14th, 16th, and 18th $\mathrm{d}$ of the experiment. The aliquots were spread on plate count agar (PCA) media in agar plates and incubated for $24 \mathrm{~h}$ at $37^{\circ} \mathrm{C}$. Subsequently, the number of bacterial colonies was determined. Different types of bacteria were identified by a private sequencing company based on the $16 \mathrm{~S}$ rDNA-based PCR analysis and included Enterobacter spp., Pseudomonas spp., and Bacillus spp.

\subsection{Expression Analyses}

Expression of Gladiolus senescence-associated genes (SAG), GgCyP1 [44] and GgDAD1 [45], and floral tissue expansion-related gene GgEXPA1 [46] was investigated in the fresh petals after $24 \mathrm{~h}$ of treatment. The Gladiolus actin gene [55] was used as a reference to normalize the transcription levels.

\subsection{Statistical Analyses}

The study was repeated thrice and the results were pooled. Tukey-Kramer's multiple range test at $p=0.05$ was used to determine significant differences between means in SPSS (PASW Ver. 21, IBM, USA). The values shown are the means \pm standard error (SE) of 12 replicates in 3 experiments $(n=36)$ at the same time.

\section{Conclusions}

This was a novel report on the morphological, physiological, biochemical, and genetic responses of cut flowers (G. grandiflorus) to the application of tree bark extracts (M. acuminata and T. cuspidata) and their main phenolic compounds as additives to holding solutions. G. grandiflorus cut spikes subjected to bark extracts showed increased longevity (up to 18 days), more opened florets, and increased floret fresh weight. Substantial reductions in stem end microbial growth were found in treated cut spikes at 50 and $80 \mathrm{mg} / 500 \mu \mathrm{L}$ MA and were associated with increased relative water content. The enhanced vegetative growth was accompanied by increased leaf chlorophyll content and a maintenance in the amounts of carotenoids. Cut spike soluble sugars and proteins as well as gas 
exchange parameters were higher in bark-extract, catechin, and protocatechuic acid treatments than in the control. Higher antioxidant activities were evident in the lipid peroxidation assay and associated with increased SOD and CAT enzymes activities and reduced accumulation of $\mathrm{H}_{2} \mathrm{O}_{2}$. These changes were associated with reduced protease activity, as evidenced by GgCyP1 (produces cysteine protease), increased expression of $G g D A D 1$ and $G g E X P A 1$, and increased overall antioxidants and phenol effects. Several mechanisms were implicated in these effects, including maintenance of water content, microbial growth control, enhanced antioxidant management, and increased sugar and protein composition. These findings indicate the possible use of bark extracts and related phenols as eco-friendly, non-toxic, and cost-effective natural preservatives for cut gladiolus flowers.

Funding: The work was supported by King Saud University, Researchers Supporting Project number (RSP-2019/118).

Acknowledgments: The author extend his appreciation to King Saud University, Researchers Supporting Project for funding this work through research group (RSP-2019/118).

Conflicts of Interest: There is no conflict of interest

\section{References}

1. Ding, C.; Lei, L.; Yao, L.; Wang, L.; Hao, X.; Li, N.; Wang, Y.; Yin, P.; Guo, G.; Yang, Y.; et al. The involvements of calcium-dependent protein kinases and catechins in tea plant [Camellia sinensis (L.) O. Kuntze] cold responses. Plant Physiol. Biochem. 2019, 143, 190-202. [CrossRef] [PubMed]

2. Shibuya, K.; Watanabe, K.; Ono, M. CRISPR/Cas9-mediated mutagenesis of the EPHEMERAL1 locus that regulates petal senescence in Japanese morning glory. Plant Physiol. Biochem. 2018, 131, 53-57. [CrossRef] [PubMed]

3. Leoni, B.; Loconsole, D.; Cristiano, G.; De Lucia, B. Comparison between Chemical Fertilization and Integrated Nutrient Management: Yield, Quality, N, and P Contents in Dendranthema grandiflorum (Ramat.) Kitam. Cultivars 2019, 9, 202. [CrossRef]

4. Tork, D.G.; Anderson, N.O.; Wyse, D.L.; Betts, K.J. Domestication of Perennial Flax Using an Ideotype Approach for Oilseed, Cut Flower, and Garden Performance. Agronomy 2019, 9, 707. [CrossRef]

5. Gourieroux, A.M.; McCully, M.E.; Holzapfel, B.P.; Scollary, G.R.; Rogiers, S.Y. Flowers regulate the growth and vascular development of the inflorescence rachis in Vitis vinifera L. Plant Physiol. Biochem. 2016, 108, 519-529. [CrossRef]

6. Van Meeteren, U.; Arévalo-Galarza, L.; Van Doorn, W. Inhibition of water uptake after dry storage of cut flowers: Role of aspired and wound-induced processes in Crysanthemum. Postharvest Biol. Technol. 2006, 41, 70-77. [CrossRef]

7. Sankat, C.K.; Mujaffar, S. Water Balance in Cut Anthurium Flowers in Storage and Its Effect on Quality; International Society for Horticultural Science (ISHS): Leuven, Belgium, 1994; pp. 723-732.

8. Singh, A.; Kumar, J.; Kumar, P. Effects of plant growth regulators and sucrose on post harvest physiology, membrane stability and vase life of cut spikes of gladiolus. Plant Growth Regul. 2008, 55, 221-229. [CrossRef]

9. Elansary, H.O.; Zin El-Abedin, T.K. Omeprazole alleviates water stress in peppermint and modulates the expression of menthol biosynthesis genes. Plant Physiol. Biochem. 2019, 139, 578-586. [CrossRef]

10. Zhang, J.; Lv, J.; Dawuda, M.M.; Xie, J.; Yu, J.; Li, J.; Zhang, X.; Tang, C.; Wang, C.; Gan, Y. Appropriate Ammonium-Nitrate Ratio Improves Nutrient Accumulation and Fruit Quality in Pepper (Capsicum annuum L.). Agronomy 2019, 9, 683. [CrossRef]

11. Sotek, Z.; Białecka, B.; Pilarczyk, B.; Drozd, R.; Pilarczyk, R.; Tomza-Marciniak, A.; Kruzhel, B.; Lysak, H.; Bakowska, M.; Vovk, S. Antioxidant Activity and Selenium and Polyphenols Content from Selected Medicinal Plants Natives from Various Areas Abundant in Selenium (Poland, Lithuania, and Western Ukraine). Processes 2019, 7, 878. [CrossRef]

12. Al-Fatimi, M. Antifungal Activity of Euclea divinorum Root and Study of its Ethnobotany and Phytopharmacology. Processes 2019, 7, 680. [CrossRef] 
13. Knee, M. Selection of biocides for use in floral preservatives. Postharvest Biol. Technol. 2000, 18, $227-234$. [CrossRef]

14. Saeed, T.; Hassan, I.; Abbasi, N.A.; Jilani, G. Effect of gibberellic acid on the vase life and oxidative activities in senescing cut gladiolus flowers. Plant Growth Regul. 2014, 72, 89-95. [CrossRef]

15. Saeed, T.; Hassan, I.; Jilani, G.; Abbasi, N.A. Zinc augments the growth and floral attributes of gladiolus, and alleviates oxidative stress in cut flowers. Sci. Hortic Amst. 2013, 164, 124-129. [CrossRef]

16. Hassan, F.A.S.; Fetouh, M.I. Does moringa leaf extract have preservative effect improving the longevity and postharvest quality of gladiolus cut spikes? Sci. Hortic Amst. 2019, 250, 287-293. [CrossRef]

17. Maity, T.R.; Samanta, A.; Datta, S. Evaluation of Piper betle mediated silver nanoparticle in post-harvest physiology in relation to vase life of cut spike of Gladiolus. Bull. Natl. Res. Cent. 2019, 43, 9. [CrossRef]

18. Chantuma, P.; Lacointe, A.; Kasemsap, P.; Thanisawanyangkura, S.; Gohet, E.; Clement, A.; Guilliot, A.; Ameglio, T.; Thaler, P. Carbohydrate storage in wood and bark of rubber trees submitted to different level of C demand induced by latex tapping. Tree Physiol. 2009, 29, 1021-1031. [CrossRef]

19. Mayans, B.; Pérez-Esteban, J.; Escolástico, C.; Eymar, E.; Masaguer, A. Evaluation of Commercial Humic Substances and Other Organic Amendments for the Immobilization of Copper Through 13C CPMAS NMR, FT-IR, and DSC Analyses. Agronomy 2019, 9, 762. [CrossRef]

20. Sakaue, Y.; Domon, H.; Oda, M.; Takenaka, S.; Kubo, M.; Fukuyama, Y.; Okiji, T.; Terao, Y. Anti-biofilm and bactericidal effects of magnolia bark-derived magnolol and honokiol on Streptococcus mutans. Microbiol. Immunol. 2016, 60, 10-16. [CrossRef]

21. Elansary, H.O.; Szopa, A.; Kubica, P.; Al-Mana, F.A.; Mahmoud, E.A.; El-Abedin, T.K.A.Z.; Mattar, M.A.; Ekiert, H. Phenolic Compounds of Catalpa speciosa, Taxus cuspidata, and Magnolia acuminata have Antioxidant and Anticancer Activity. Molecules 2019, 24, 412. [CrossRef]

22. Bajpai, V.K.; Sharma, A.; Baek, K.-H. Antibacterial Mechanism of Action of Taxus cuspidata Stem Essential Oil against Selected Foodborne Pathogens. Food Saf. 2013, 33, 348-359. [CrossRef]

23. Grobelna, A.; Kalisz, S.; Kieliszek, M. The Effect of the Addition of Blue Honeysuckle Berry Juice to Apple Juice on the Selected Quality Characteristics, Anthocyanin Stability, and Antioxidant Properties. Biomolecules 2019, 9, 744. [CrossRef]

24. Elansary, H.O.; Szopa, A.; Kubica, P.; Ekiert, H.; Mattar, M.; Al-Yafrasi, M.A.; El-Ansary, D.O.; Zin El-Abedin, T.K.; Yessoufou, K. Polyphenol Profile and Pharmaceutical Potential of Quercus spp. Bark Extracts. Plants 2019, 8, 486. [CrossRef]

25. Andrade, C.; Ferreres, F.; Gomes, G.M.N.; Duangsrisai, S.; Srisombat, N.; Vajrodaya, S.; Pereira, M.D.; Gil-Izquierdo, A.; Andrade, B.P.; Valentão, P. Phenolic Profiling and Biological Potential of Ficus curtipes Corner Leaves and Stem Bark: 5-Lipoxygenase Inhibition and Interference with NO Levels in LPS-Stimulated RAW 264.7 Macrophages. Biomolecules 2019, 9, 400. [CrossRef] [PubMed]

26. Maity, T.R.; Samanta, A.; Jana, D.; Saha, B.; Datta, S. Effect of Piper betle leaf extract on post-harvest physiology and vascular blockage in relation to vase life and keeping quality of cut spike of tuberose (Polianthes tuberosa $\mathrm{L}$. cv. Single). Indian J. Plant Physiol. 2014, 19, 250-256. [CrossRef]

27. Cavaiuolo, M.; Cocetta, G.; Ferrante, A. The Antioxidants Changes in Ornamental Flowers during Development and Senescence. Antioxidants 2013, 2, 132. [CrossRef] [PubMed]

28. McCormick, A.J.; Cramer, M.D.; Watt, D.A. Regulation of photosynthesis by sugars in sugarcane leaves. J. Plant Physiol. 2008, 165, 1817-1829. [CrossRef]

29. Nikinmaa, E.; Sievänen, R.; Hölttä, T. Dynamics of leaf gas exchange, xylem and phloem transport, water potential and carbohydrate concentration in a realistic 3-D model tree crown. Ann. Bot. 2014, 114, 653-666. [CrossRef] [PubMed]

30. Nazemi Rafi, Z.; Ramezanian, A. Vase life of cut rose cultivars 'Avalanche' and 'Fiesta' as affected by Nano-Silver and S-carvone treatments. S. Afr. J. Bot. 2013, 86, 68-72. [CrossRef]

31. Semaming, Y.; Pannengpetch, P.; Chattipakorn, S.C.; Chattipakorn, N. Pharmacological Properties of Protocatechuic Acid and Its Potential Roles as Complementary Medicine. Evid. Based Complement. Altern. Med. 2015, 2015, 593902. [CrossRef] [PubMed]

32. Taylor, P.W.; Hamilton-Miller, J.M.T.; Stapleton, P.D. Antimicrobial properties of green tea catechins. Food Sci. Technol. Bull. 2005, 2, 71-81. [CrossRef] [PubMed] 
33. Borges, J.d.C.; Perim, M.C.; de Castro, R.O.; Araújo, T.A.d.S.; Peixoto Sobrinho, T.J.d.S.; da Silva, A.C.O.; Mariano, S.M.B.; Carreiro, S.C.; Pranchevicius, M.C.d.S. Evaluation of antibacterial activity of the bark and leaf extracts of Brosimum gaudichaudii Trécul against multidrug resistant strains. Nat. Prod. Res. 2017, 31, 2931-2935. [CrossRef] [PubMed]

34. Ahmad, S.S.; Tahir, I. Regulatory role of phenols in flower development and senescence in the genus Iris. Indian J. Plant Physiol. 2017, 22, 135-140. [CrossRef]

35. Naing, A.H.; Win, N.M.; Han, J.-S.; Lim, K.B.; Kim, C.K. Role of Nano-silver and the Bacterial Strain Enterobacter cloacae in Increasing Vase Life of Cut Carnation 'Omea'. Front. Plant Sci. 2017, 8, 1590. [CrossRef] [PubMed]

36. Put, H.M.C. Micro-organisms from freshly harvested cut flower stems and developing during the vase life of chrysanthemum, gerbera and rose cultivars. Sci. Hortic Amst. 1990, 43, 129-144. [CrossRef]

37. Mitani, T.; Ota, K.; Inaba, N.; Kishida, K.; Koyama, H.A. Antimicrobial Activity of the Phenolic Compounds of Prunus mume against Enterobacteria. Biol. Pharm. Bull. 2018, 41, 208-212. [CrossRef]

38. Elansary, H.O.; Szopa, A.; Klimek-Szczykutowicz, M.; Jafernik, K.; Ekiert, H.; Mahmoud, E.A.; Barakat, A.A.; El-Ansary, D.O. Mammillaria Species-Polyphenols Studies and Anti-Cancer, Anti-Oxidant, and Anti-Bacterial Activities. Molecules 2019, 25, 131. [CrossRef]

39. Elansary, H.O.; Salem, M.Z.M.; Ashmawy, N.A.; Yessoufou, K.; El-Settawy, A.A.A. In vitro antibacterial, antifungal and antioxidant activities of Eucalyptus spp. leaf extracts related to phenolic composition. Nat. Prod. Res. 2017, 31, 2927-2930. [CrossRef]

40. Elansary, H.O.; Mahmoud, A.E.; El-Ansary, D.O.; Mattar, M.A. Effects of Water Stress and Modern Biostimulants on Growth and Quality Characteristics of Mint. Agronomy 2019, 10, 6. [CrossRef]

41. Khenizy, S.A.; Abd El-Moneim, A.M.; Abdel-Fattah, G.H. Effect of natural extracts on vase life of Gypsophila cut flowers. Sci. J. Flowers Ornam. Plants 2014, 1, 1-16. [CrossRef]

42. Gill, S.S.; Tuteja, N. Reactive oxygen species and antioxidant machinery in abiotic stress tolerance in crop plants. Plant Physiol. Biochem. 2010, 48. [CrossRef] [PubMed]

43. Saeed, T.; Hassana, I.; Abbasia, N.A.; Jilani, G.J.S.H. Antioxidative activities and qualitative changes in gladiolus cutflowers in response to salicylic acid application. Sci. Hortic Amst. 2016, 210. [CrossRef]

44. Dwivedi, S.K.; Arora, A.; Singh, V.P.; Sairam, R.; Bhattacharya, R.C. Effect of sodium nitroprusside on differential activity of antioxidants and expression of SAGs in relation to vase life of gladiolus cut flowers. Sci. Hortic Amst. 2016, 210, 158-165. [CrossRef]

45. Yamada, T.; Takatsu, Y.; Kasumi, M.; Marubashi, W.; Ichimura, K. A homolog of the defender against apoptotic death gene (DAD1) in senescing gladiolus petals is down-regulated prior to the onset of programmed cell death. Plant Physiol. 2004, 161, 1281-1283. [CrossRef] [PubMed]

46. Azeez, A.; Sane, A.P.; Tripathi, S.K.; Bhatnagar, D.; Nath, P. The gladiolus GgEXPA1 is a GA-responsive alpha-expansin gene expressed ubiquitously during expansion of all floral tissues and leaves but repressed during organ senescence. Postharvest Biol. Technol. 2010, 58, 48-56. [CrossRef]

47. El-Esawi, M.A.; Elansary, H.O.; El-Shanhorey, N.A.; Abdel-Hamid, A.M.E.; Ali, H.M.; Elshikh, M.S. Salicylic Acid-Regulated Antioxidant Mechanisms and Gene Expression Enhance Rosemary Performance under Saline Conditions. Front. Physiol. 2017, 8. [CrossRef]

48. Irigoyen, J.J.; Einerich, D.W.; Sánchez-Díaz, M. Water stress induced changes in concentrations of proline and total soluble sugars in nodulated alfalfa (Medicago sativd) plants. Physiol. Plant. 1992, 84, 55-60. [CrossRef]

49. Olajuyigbe, O.O.; Afolayan, A.J. Phenolic content and antioxidant property of the bark extracts of Ziziphus mucronata Willd. subsp. mucronata Willd. BMC Complement. Altern. Med. 2011, 11, 130. [CrossRef]

50. Magel, E.; Einig, W.; Hampp, R. Carbohydrates in trees. In Developments in Crop Science; Gupta, A.K., Kaur, N., Eds.; Elsevier: Amsterdam, The Netherlands, 2000; Volume 26, pp. 317-336.

51. He, S.; Joyce, D.C.; Irving, D.E.; Faragher, J.D. Stem end blockage in cut Grevillea 'Crimson Yul-lo' inflorescences. Postharvest Biol. Technol. 2006, 41, 78-84. [CrossRef]

52. Weatherley, P.E. Studies in water relations of cotton plants I. The field measurement of water deficit in leaves. New Phytol. 1950, 49, 81-97. [CrossRef]

53. Arnon, D.I. Copper enzymes in isolated chloroplasts. polyphenoloxidase in Beta vulgaris. Plant Physiol. 1949, 24, 1-15. [CrossRef] [PubMed] 
54. Elansary, H.O.; Yessoufou, K.; Abdel-Hamid, A.M.E.; El-Esawi, M.A.; Ali, H.M.; Elshikh, M.S. Seaweed Extracts Enhance Salam Turfgrass Performance during Prolonged Irrigation Intervals and Saline Shock. Front. Plant Sci. 2017, 8. [CrossRef] [PubMed]

55. Kamo, K.; Kim, A.-Y.; Park, S.H.; Joung, Y.H. The 5'UTR-intron of the Gladiolus polyubiquitin promoter GUBQ1 enhances translation efficiency in Gladiolus and Arabidopsis. BMC Plant Biol. 2012, 12, 79. [CrossRef] [PubMed]

(C) 2020 by the author. Licensee MDPI, Basel, Switzerland. This article is an open access article distributed under the terms and conditions of the Creative Commons Attribution (CC BY) license (http://creativecommons.org/licenses/by/4.0/). 